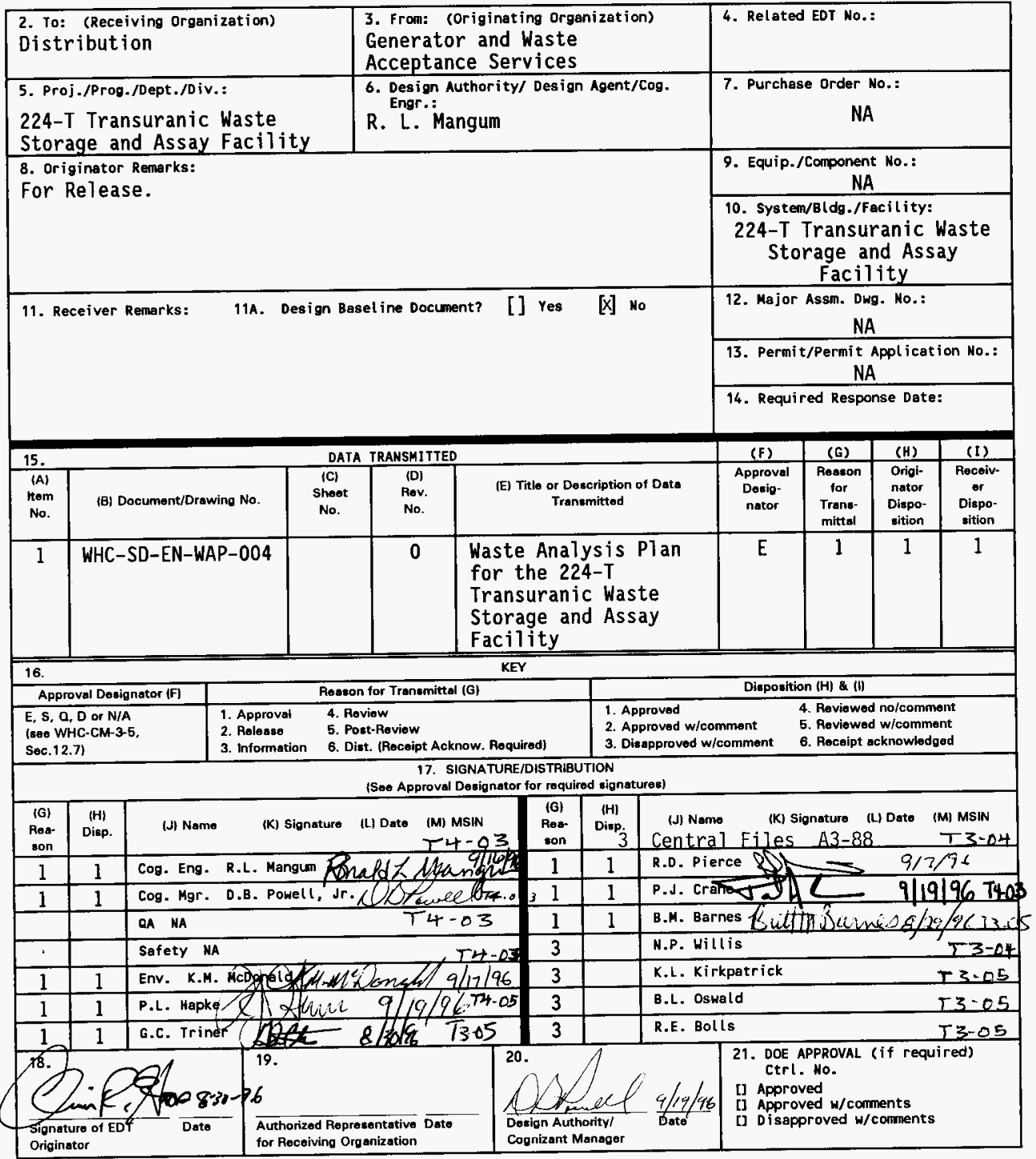

BD-7400-172-2 (05/96) GEF097 


\section{Waste Analysis Plan for the 224-T Transuranic Waste Storage and Assay Facility}

\section{Chris R. Haas}

Westinghouse Hanford Company, Richland, WA 99352

U.S. Department of Energy Contract DE-AC06-87RL10930

$\begin{array}{lll}\text { EDT/ECN: } & 619277 & \text { UC: } 2000 \\ \text { Org Code: } & 87600 & \text { Charge Code: }\end{array}$

Key Words: 224-T, TRUSAF, transuranic waste, mixed waste, low-level waste, waste acceptance, waste designation, waste characterization, QA/QC, sampling and analysis, certification program summaries.

Abstract: This waste analysis plan (WAP) has been prepared for the 224-T Transuranic Waste Storage and Assay Facility which is located in the 200 West Area of the Hanford Facility, Richland, Washington. This WAP documents the methods used to characterize, and obtain and analyze representative samples of waste managed at this unit.

TRADEMARK DISCLAIMER. Reference herein to any specific comercial product, process, or service by trade name, tradenark, manufacturer, or otherwise, does not necessarily constitute or imply its endorsement, recomendation, or favoring by the United States Government or any agency thereof or its contractors or subcontractors.

Printed in the United States of America. To obtain copies of this document, contact: WHC/BCS Document Control Services, P.O. Box 1970, Mailstop H6-08, Richland WA 99352, Phone (509) 372-2420; Fax (509) 376-4989.
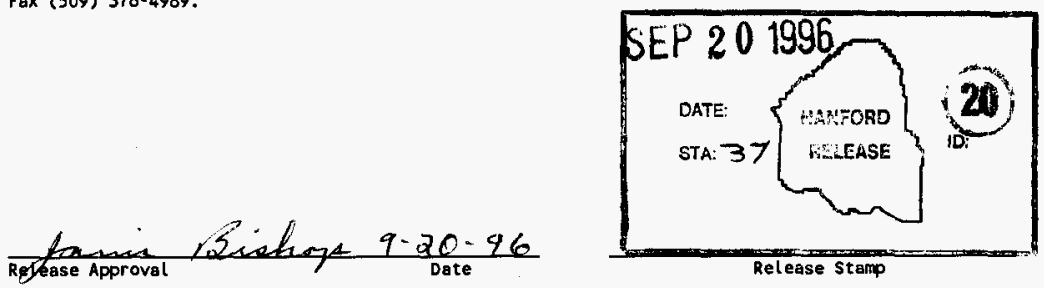

\section{Approved for Public Release}


WHC-SD-EN-WAP-004, Rev. 0

This page intentionally left blank. 
WHC-SD-EN-WAP-004, Rev. 0

\section{CONTENTS}

\section{GLOSSARY}

METRIC CONVERSION CHART

1.0 FACILITY DESCRIPTION . . . . . . . . . . . . . . . . . . . 1.1 224-T TRANSURANIC WASTE STORAGE AND ASSAY FACILITY

DESCRIPTION . . . . . . . . . . . . . . . 1-1

1.1.1 Real-Time Radiography Room . . . . . . . . . 1-2

1.1.2 Transuranic Waste Assayer Room ........ . 1-2

1.1.3 Assay Control Room and Storage Unit Operations

office.................. 1-2

1.1 .4 Elevator and Stairways . . . . . . . . . 1-3

1.1.5 Heating and Ventilation Mechanical Room ...... 1-3

1.1 .6 Waste Storage Modules ............. 1-3

1.1.6.1 Receiving Area ............. 1-3

1.1.6.2 Temporary Staging Area . . . . . . . 1-3

1.1.6.3 First Floor Storage Moduies . . . . . . . 1-3

1.1.6.4 Second Floor Storage Modules ........ 1-4

1.1.6.5 Third Floor Storage Modules . . . . . 1-4

1.2 DESCRIPTION OF THE 224-T TRANSURANIC WASTE STORAGE AND ASSAY

FACILITY PROCESS AND ACTIVITIES . . . . . . . . . 1-4

2.0 WASTE ACCEPTANCE PROGRAM ............... 2-1

2.1 WASTE CERTIFICATION PROGRAM .............. 2-1

2.1.1 Waste Certification Information ........ 2-1

2.1 .2 Waste Characterization .............. 2-1

2.1 .3 Process Knowledge .............. 2- . . 2-3

2.1 .4 Sampling and Analysis ............. 2-3

2.1 .5 Analytical Methodologies . . . . . . . . . . 2-3

2.2 PRE-SHIPMENT REVIEW . . . . . . . . . . . 2-4

2.2.1 Pre-Shipment Review Process .......... 2-4

2.2.2 Methodology to Ensure Compliance with Land Disposal

Restrictions Requirements ........... 2-4

2.3 WASTE VERIFICATION ............... 2-5

2.4 CORRECTIVE ACTIONS .................. . . . . . . . . . .

2.4.1 Manifest Discrepancies . . . . . . . . 2-7

2.4 .2 Nonconformances ............. 2-7

2.4.3 Resolution of Nonconformances ......... 2-8

2.4.4 Periodic Evaluation of Nonconformances . . . . . . 2-9

2.5 ACCEPTING THE WASTE ................... 2- . . .

2.6 MANIFEST SYSTEM . . . . . . . . . . . . . . . . . 2-10

2.7 TRACKING SYSTEM . . . . . . . . . . . . 2-11

2.8 ADDITIONAL REQUIREMENTS FOR WASTE GENERATED OFFSITE . . . 2-11

2.9 METHODOLOGY FOR IGNITABLE, REACTIVE, OR INCOMPATIBLE $\ldots \ldots \ldots$. . . . . . . . . . . . . . .

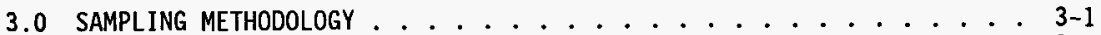

3.1 SAMPLING METHODOLOGY ................. $3-1$

3.2 SAMPLING STRATEGIES . . . . . . . . . . . . 3-1 


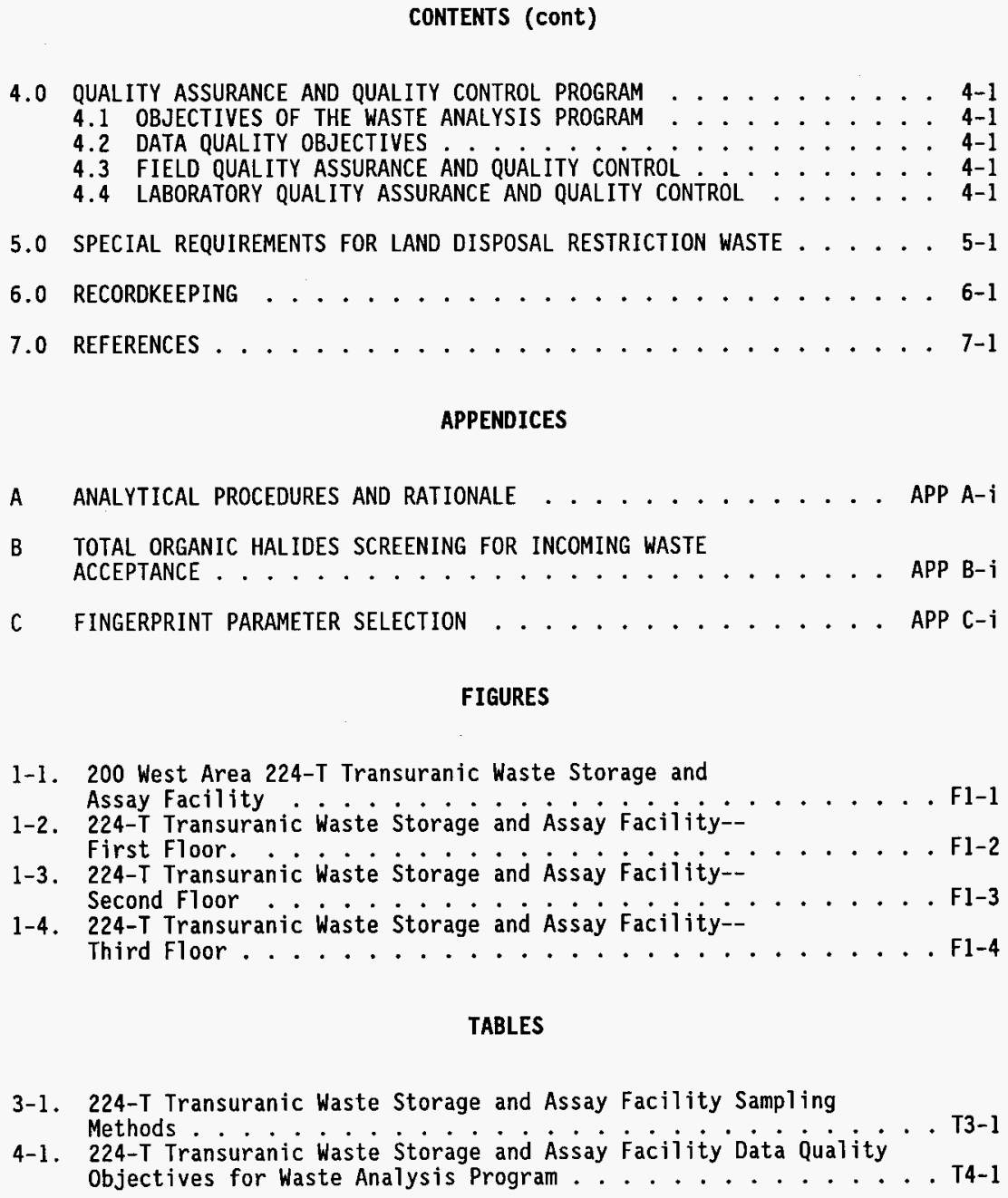

1-1. 200 West Area 224-T Transuranic Waste Storage and Assay Facility . . . . . . . . . . . . . . . . . . . . F1-1

1-2. 224-T Transuranic Waste Storage and Assay Facility--

First Floor. . . . . . . . . . . . . . . . . Fl-2

1-3. 224-T Transuranic Waste Storage and Assay Facility--

Second Floor . . . . . . . . . . . . . . . . . . . . Fl-3

1-4. 224-T Transuranic Waste Storage and Assay Facility--

Third Floor............. . . . . . . . . . F1-4

\section{TABLES}

3-1. 224-T Transuranic Waste Storage and Assay Facility Sampling

Methods..................... . . . . . . . . 1

4-1. 224-T Transuranic Waste Storage and Assay Facility Data Quality Objectives for Waste Analys is Program . . . . . . . . . . . T4-1 
WHC-SD-EN-WAP-004, Rev. 0

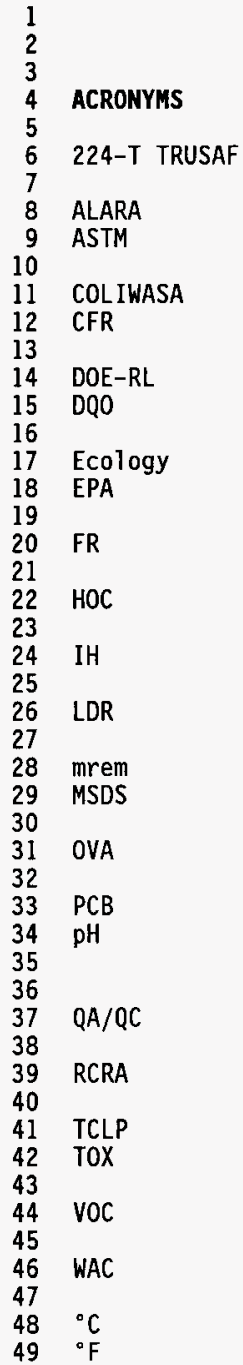

\section{GLOSSARY}

224-T Transuranic Waste Storage and Assay Facility

as low as reasonably achievable American Society for Testing and Materials

composite liquid waste sampler

Code of Federal Regulations

U.S. Department of Energy, Richland Operations Office data quality objective

Washington State Department of Ecology

U.S. Environmental Protection Agency

Federal Register

halogenated organic compound

industrial hygienist

land disposal restriction

millirem (roentgen equivalent man)

material safety data sheet

organic vapor analyzer

polychlorinated biphenyl

negative logarithm of the hydrogen ion concentration in aqueous solutions

quality assurance and quality control

Resource Conservation and Recovery Act of 1976

toxicity characteristics leaching procedure total organic halides

volatile organic compound

Washington Administrative Code

degrees Celsius

degrees Fahrenheit 


\section{METRIC CONVERSION CHART}

The following conversion chart is provided to the reader as a tool to aid in conversion.

Into metric units

out of metric units

\begin{tabular}{|c|c|c|c|c|c|}
\hline If you know & $\begin{array}{l}\text { Multiply } \\
\text { by }\end{array}$ & To get & If you know & $\begin{array}{l}\text { Multiply } \\
\text { by }\end{array}$ & To get \\
\hline \multicolumn{3}{|c|}{ Length } & \multicolumn{3}{|c|}{ Length } \\
\hline inches & 25.40 & millimeters & millimeters & 0.0393 & inches \\
\hline inches & 2.54 & centimeters & centimeters & 0.393 & inches \\
\hline feet & 0.3048 & meters & meters & 3.2808 & feet \\
\hline yards & 0.914 & meters & meters & 1.09 & yards \\
\hline miles & 1.609 & kilometers & kilometers & 0.62 & miles \\
\hline \multicolumn{3}{|c|}{ Area } & \multicolumn{3}{|c|}{ Area } \\
\hline $\begin{array}{l}\text { square } \\
\text { inches }\end{array}$ & 6.4516 & $\begin{array}{l}\text { square } \\
\text { centimeters }\end{array}$ & $\begin{array}{l}\text { square } \\
\text { centimeters }\end{array}$ & 0.155 & $\begin{array}{l}\text { square } \\
\text { inches }\end{array}$ \\
\hline square feet & 0.092 & $\begin{array}{l}\text { square } \\
\text { meters }\end{array}$ & $\begin{array}{l}\text { square } \\
\text { meters }\end{array}$ & 10.7639 & $\begin{array}{l}\text { square } \\
\text { feet }\end{array}$ \\
\hline $\begin{array}{l}\text { square } \\
\text { yards }\end{array}$ & 0.836 & $\begin{array}{l}\text { square } \\
\text { meters }\end{array}$ & $\begin{array}{l}\text { square } \\
\text { meters }\end{array}$ & 1.20 & $\begin{array}{l}\text { square } \\
\text { yards }\end{array}$ \\
\hline $\begin{array}{l}\text { square } \\
\text { miles }\end{array}$ & 2.59 & $\begin{array}{l}\text { square } \\
\text { kilometers }\end{array}$ & $\begin{array}{l}\text { square } \\
\text { kilometers }\end{array}$ & 0.39 & $\begin{array}{l}\text { square } \\
\text { miles }\end{array}$ \\
\hline acres & 0.404 & hectares & hectares & 2.471 & acres \\
\hline \multicolumn{3}{|c|}{ Mass (weight) } & \multicolumn{3}{|c|}{ Mass (weight) } \\
\hline ounces & 28.35 & grams & grams & 0.0352 & ounces \\
\hline pounds & 0.453 & ki lograms & kilograms & 2.2046 & pounds \\
\hline short ton & 0.907 & metric ton & metric ton & 1.10 & short ton \\
\hline \multicolumn{3}{|c|}{ Volume } & \multicolumn{3}{|c|}{ Volume } \\
\hline $\begin{array}{l}\text { fluid } \\
\text { ounces }\end{array}$ & 29.57 & milliliters & milliliters & 0.03 & $\begin{array}{l}\text { fluid } \\
\text { ounces }\end{array}$ \\
\hline quarts & 0.95 & Titers & Titers & 1.057 & quarts \\
\hline gallons & 3.79 & liters & Titers & 0.26 & gallons \\
\hline cubic feet & 0.03 & $\begin{array}{l}\text { cubic } \\
\text { meters }\end{array}$ & $\begin{array}{l}\text { cubic } \\
\text { meters }\end{array}$ & 35.3147 & cubic feet \\
\hline cubic yards & 0.76456 & $\begin{array}{l}\text { cubic } \\
\text { meters }\end{array}$ & $\begin{array}{l}\text { cubic } \\
\text { meters }\end{array}$ & 1.308 & $\begin{array}{l}\text { cubic } \\
\text { yards }\end{array}$ \\
\hline \multicolumn{3}{|c|}{ Temperature } & \multicolumn{3}{|c|}{ Temperature } \\
\hline Fahrenheit & $\begin{array}{l}\text { subtract } \\
32 \text { then } \\
\text { multiply } \\
\text { by } 5 / 9 \text { ths }\end{array}$ & Celsius & Celsius & $\begin{array}{l}\text { multiply } \\
\text { by } \\
9 / 5 \text { ths, } \\
\text { then add } \\
32\end{array}$ & Fahrenheit \\
\hline
\end{tabular}

Source: Engineering Unit Conversions, M. R. Lindeburg, PE., Second Ed., 1990, Professional Publications, Inc., Belmont, California. 


\subsection{FACILITY DESCRIPTION}

The purpose of this waste analysis plan (WAP) is to document the waste acceptance process, sampling methodologies, analytical techniques, and overall processes that are undertaken for waste accepted for storage at the 224-T Transuranic Waste Storage and Assay Facility (224-T TRUSAF), located in the 200 West Area of the Hanford Facility, Richland, Washington (Figure 1-1). Because dangerous waste does not include the source, special nuclear, and by-product material components of mixed waste, radionuclides are not within the scope of this documentation. The information on radionuclides is provided only for general knowledge. Acceptance methods for waste that is currently in inventory within onsite treatment, storage, and/or disposal units under the cognizance of the same management as the 224-T TRUSAF will have project specific waste analysis or equivalent plans developed to ensure proper characterization before active management.

\subsection{4-T TRANSURANIC WASTE STORAGE AND ASSAY FACILITY DESCRIPTION}

The primary mission of the 224-T TRUSAF is to store transuranic, transuranic mixed, low-level mixed, and low-level waste. The 224-T TRUSAF also has the capability to store retrieved transuranic mixed waste until characterization is performed in another TSD unit.

The 224-T Building (Figures 1-2, 1-3, and 1-4) is a permanent structure constructed entirely of reinforced concrete. The 224-T Building originally was constructed in the early 1940's as a chemical processing unit for purifying liquid plutonium nitrate by the lanthanum fluoride process. The 224-T Building remained idle for several years after new processes made the lanthanum fluoride process obsolete. In 1975, the mission of the 224-T Building changed to that of storing liquid and solid plutonium and plutonium scrap. To meet the requirements for this new mission and the criteria for storing plutonium, the 224-T Building underwent major structural upgrades and modifications. The modifications included sealing off the areas previously used for chemical separations from personnel entry, and tornado and seismic reinforcement. The three floors of the building, which contain six radiologically contaminated process cells (cells $A$ through $F$ ), were sealed completely from the eastern third of the building.

In 1985, the current mission of the 224-T Building was initiated for storing transuranic, transuranic mixed, low-level, and low-level mixed waste, and the 224-T Building was redesignated as 224-T TRUSAF.

The three floors of the 224-T TRUSAF are connected by stairway $A$ at the north end of the building, by stairway $B$ at the south end of the building, and by an elevator adjacent to stairway $A$. There also is a concrete elevator loading deck off the elevator on the outside of the building. The first floor contains storage modules, a restroom, a heating and ventilation mechanical room, an elevator, a transuranic waste assayer room, and a real-time radiography room. The storage modules on the first floor are in open areas and are clearly marked on the floor. The second and third floors contain open 
storage modules that are marked on the floor. The roof contains the ventilation exhaust equipment and a penthouse. The penthouse houses the elevator mechanical equipment.

Each floor has curbed entrances to accumulate released liquids. collected or contained liquids can be removed using hand pumps, absorbents, or a vacuum system. The floors of the 224-T TRUSAF are sealed to meet secondary containment requirements. The fire protection system consists of a dry-pipe fire system. The heating and ventilation system exhausts air at approximately four air changes per hour and the system maintains a negative pressure with respect to the atmosphere.

The 224-T TRUSAF consists of the following areas:

- Real-time radiography room

- Transuranic waste assayer room

- Assay control room and storage unit operations office

- Elevator and stairways

- Heating and ventilation mechanical room

- Waste storage and holding areas

- Incoming waste receiving area

- Storage modules

- Acids

- Caustics

- Mixed waste

- Nonhazardous

- Roof area.

Each area of the 224-T TRUSAF is addressed in the following sections.

\subsubsection{Rea1-Time Radiography Room}

The real-time radiography room houses the real-time radiographic $x-r a y$ system. The real-time radiography system is operated from a desk and control terminal. In the real-time radiography room, there is a roll-up door used for building services.

\subsubsection{Transuranic Waste Assayer Room}

The transuranic waste assayer room houses the transuranic waste assayer. only one container at a time is staged here for assaying.

\subsubsection{Assay Control Room and Storage Unit Operations Office}

The assay control room and storage unit operations office serve as the operations center. The transuranic waste assayer is operated from this office. Operating logs and records are maintained here in file cabinets.

\subsubsection{Elevator and Stairways}


The elevator and stairways service all three floors of the 224-T TRUSAF and are located on the west side of the storage building. The elevator is used for transporting waste to the upper floors for storage, for moving large or heavy equipment, and for outloading waste.

\subsubsection{Heating and Ventilation Mechanical Room}

The heating and ventilation mechanical room is on the west central side of the first floor. The heating and ventilation system provides a constant negative pressure with respect to the atmosphere and the process cells.

\subsubsection{Waste Storage Modules}

Waste storage modules on all three floors are open-array storage modules, delineated by markings on the floor to prevent inadvertent commingling of waste forms. Transuranic mixed waste is stored based on both transuranic element content and dangerous waste constituents.

1.1.6.1 Receiving Area. The receiving area is located in the southeast corner of the first floor. To allow the movement of a forklift, a double metal door is provided for entrance to the receiving area. A concrete pad outside of the door is provided for unloading waste. The receiving area also contains an electronic scale to weigh the waste containers. The area is two floors high in the extreme southeast portion of the receiving area. A portion of the area is only one floor high and contains a 909-kilogram crane. This crane is used for container-overpacking operations and drum weighing.

1.1.6.2 Temporary Staging Area. The temporary staging area is located at the southeast end of the 224-T TRUSAF. Transuranic mixed waste received for evaluation against waste acceptance criteria and for potential storage is placed in the temporary staging area until off-loading operations are complete. When the receiving doors have been closed, the waste is transferred to the initial storage module.

1.1.6.3 First Floor Storage Modules. The first floor storage modules are used for storage before examination and transfer of waste to other locations (i.e., upper floor storage, return to generators and/or generating units, another TSD unit). Because of the irregularity in frequency, amount, and type of waste received, the first floor storage modules are flexible storage modules. Incompatible waste modules are adjusted as necessary to accommodate the size and waste incompatibilities of each shipment. All transuranic mixed waste is separated into compatible modules, two containers high, two containers wide, and as long as necessary to accommodate the amount of the waste type and to allow for inspection. Transuranic mixed waste modules are separated by a distance of at least 76.2 centimeters, are separated from other modules, and are labeled by waste category. When transuranic mixed waste is received, the waste is administratively processed for storage as soon as possible. Waste is administratively processed by logging the waste in, subjecting the waste to nondestructive examination as necessary, and providing final disposition for the waste. 
1 1.1.6.4 Second Floor Storage Modules. The majority of the second floor presently is reserved for transuranic waste. Transuranic mixed waste also is stored on the second floor. Transuranic mixed waste (acids) is stored in open-array modules, two containers wide, labeled as to waste type, and separated from all other modules by a distance of at least 76.2 centimeters (Figure 2-4). Storage module locations will be adjusted as necessary to accommodate future waste storage. Incompatible dangerous waste is separated by being $p$ laced in different rooms on the second floor.

1.1.6.5 Third Floor Storage Modules. The third floor storage area presently contains two waste storage modules. Additional modules might be added to accommodate future waste storage. Modules 3-1 are for transuranic mixed waste (caustic and other). In modules 3-1, transuranic mixed waste is stored in open arrays, two containers wide, two containers high, labeled by waste type, and separated from all other modules by a distance of at least 76.2 centimeters. Modules 3-2 are for transuranic waste. No incompatible transuranic mixed waste is stored on the third floor.

\subsection{DESCRIPTION OF THE 224-T TRANSURANIC WASTE STORAGE AND ASSAY FACILITY PROCESS AND ACTIVITIES}

The 224-T TRUSAF receives containerized mixed waste from onsite generating units as well as offsite generators. On receipt of the transuranic waste, transuranic mixed waste, low-level waste, or low-level mixed waste, the 224-T TRUSAF operations personnel perform an inspection (exterior on7y) of the waste container(s) and associated documentation, a neutron assay of the waste container might be performed to determine fissile isotope content, as well as an examination with a real-time radiography system to confirm the absence of prohibited items (e.g., free liquids). If the waste container(s) and accompanying documentation are determined to be acceptable, the 224-T TRUSAF operations personnel store the waste or ship it to another TSD for storage. 
WHC-SD-EN-WAP-004, Rev. 0

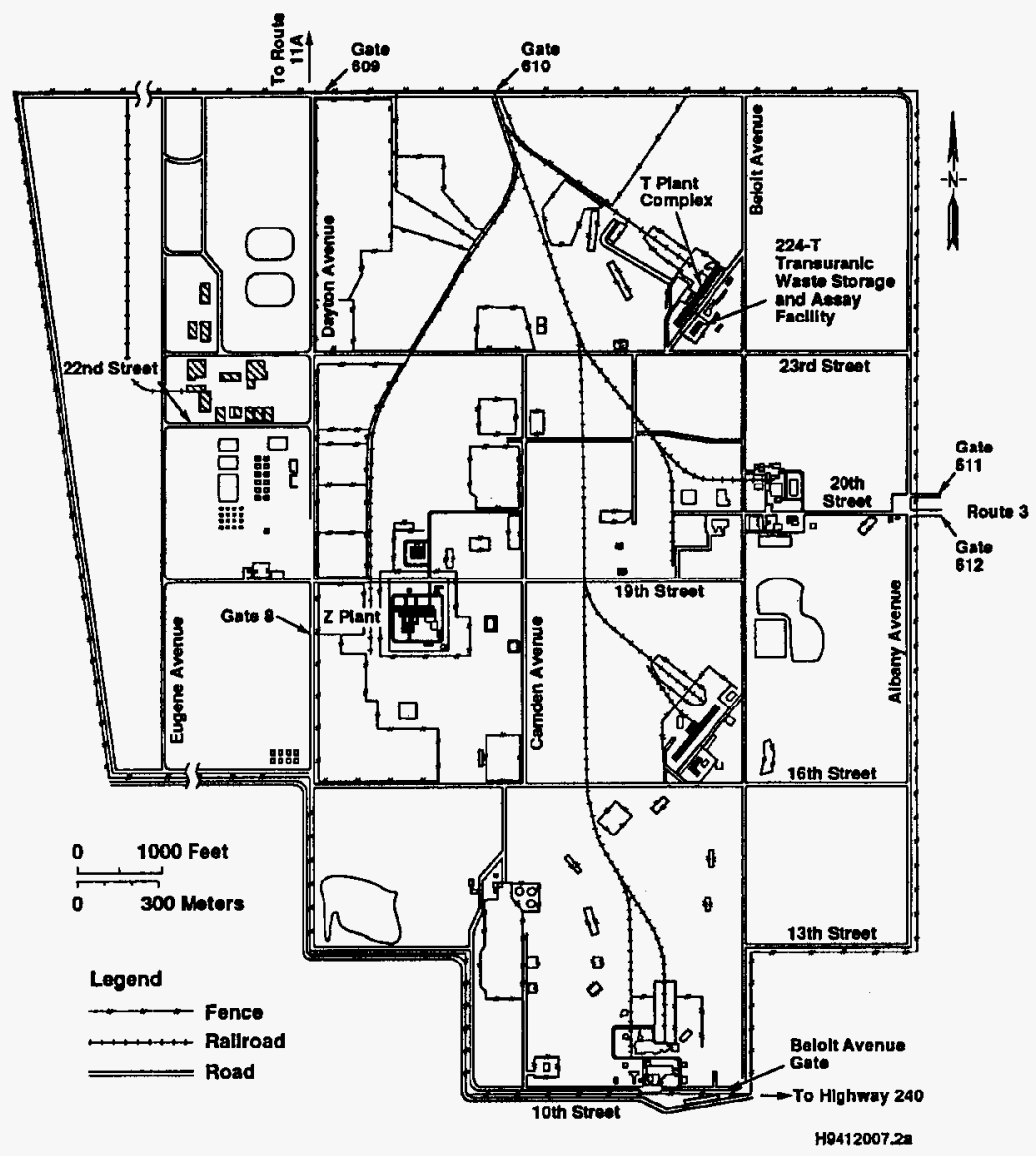

Figure 1-1. 200 West Area 224-T Transuranic Waste Storage and Assay Facility. 


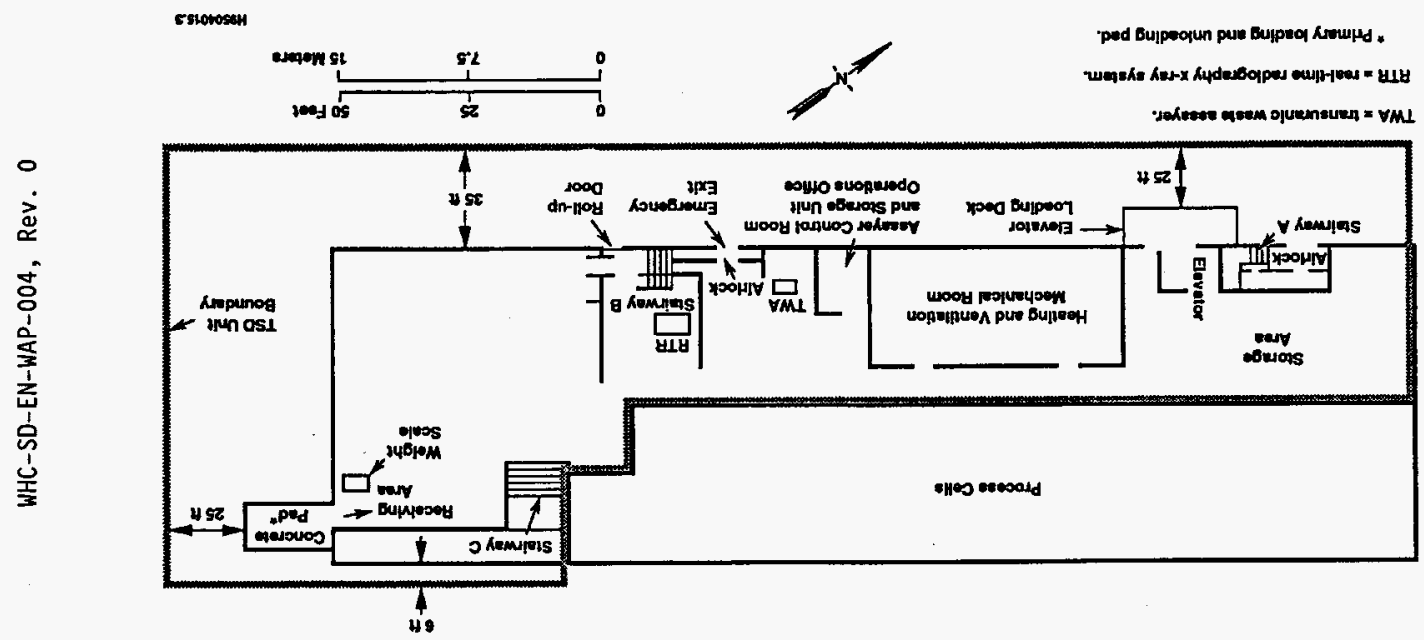

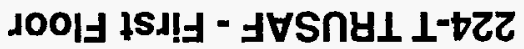


WHC-SD-EN-WAP-004, Rev. 0

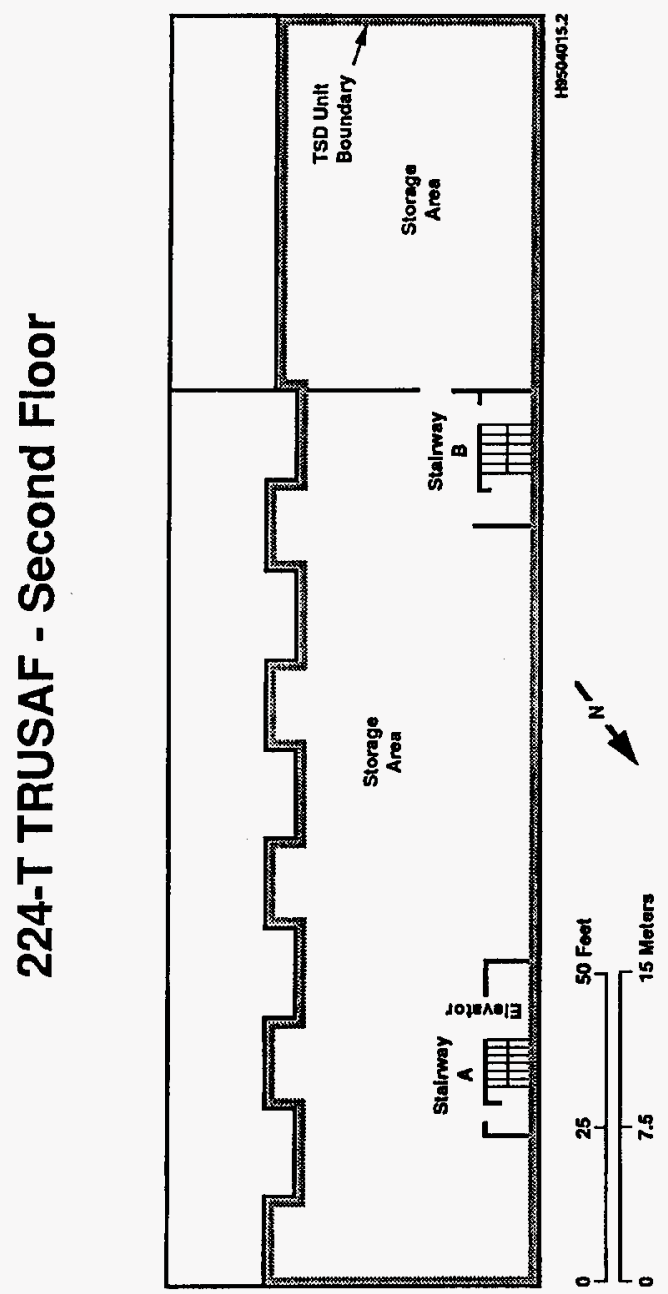

Figure 1-3. 224-T Transuranic Waste Storage and Assay Facility--Second Floor. 


\section{4-T TRUSAF - Third Floor}
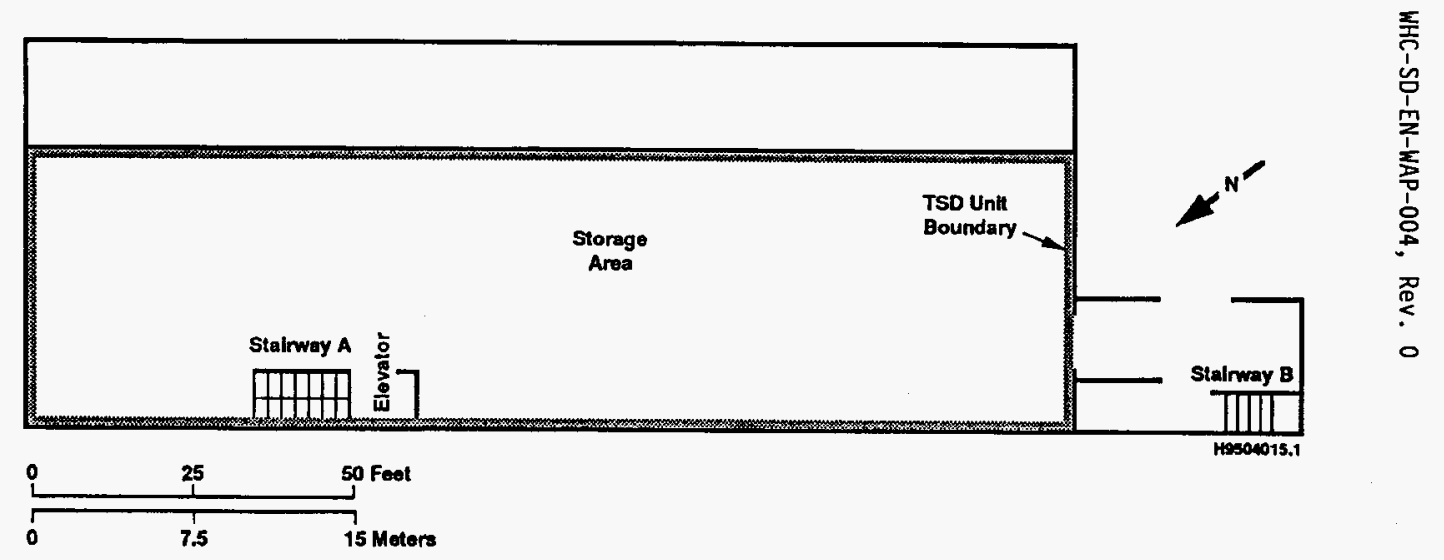
WHC-SD-EN-WAP-004, Rev. 0

\subsection{WASTE ACCEPTANCE PROGRAM}

This section covers the waste acceptance process for the proper management of waste in the 224-T TRUSAF.

\subsection{WASTE CERTIFICATION PROGRAM}

The onsite generating unit or offsite generator (for the purposes of this WAP, permitted treatment and storage facilities are classified as either onsite generating units or offsite generators) must have a program to certify characterization of their waste. The onsite generating unit or offsite generator must document their waste certification program on a stream-bystream basis in the form of waste certification summaries. Each waste certification summary must include a description of methods used for characterizing the applicable waste stream(s). Characterization efforts provide the data quality needed for management of the waste and ensure that waste is packaged properly. A description of the type of information that must be included in a waste certification summary is provided in the following sections.

\subsubsection{Waste Certification Information}

The basic information required for each waste stream includes the following:

- General information on waste generating process

- Physical characteristics of the waste

- Chemical characteristics of the waste

- Radiological characteristics of the waste

- Packaging

- Supporting documentation (e.g., laboratory analysis, etc.)

- Land disposal restriction (LDR) certification (if applicable).

\subsubsection{Waste Characterization}

Waste must be characterized sufficiently to ensure that the waste meets the acceptance criteria for storage. It is the responsibility of onsite generating units and offsite generators to completely and correctly identify and quantify the dangerous constituents of their waste. Characterization can occur using either process knowledge or detailed laboratory analysis or a combination of both. Adequate process knowledge and/or analysis must be available to accurately identify all existing dangerous waste numbers in accordance with WAC 173-303-070, as well as determine the LDR status of the waste. The following are specific characterization techniques, depending on the waste generating process. 
- Characterization of consistently-generated waste streams

If the waste is being generated through a continuing process, such that the composition of the waste is not expected to vary appreciably over time, waste characterization requirements can be met through administrative and engineering controls on the process. Initially, the waste stream must be characterized through a campaign of sampling and analysis. However, if it can be shown that certain parameters are expected to remain within known limits or where representative sampling is not possible because of the physical form of the waste, gross measurements (e.g., $\mathrm{pH}$, radioactivity screening) and related process knowledge could be substituted for specific chemical sampling and analysis. For each waste stream, the following information should be provided in the waste certification summary:

- Specific parameters expected to remain constant (metal content, radionuclide content, etc.)

- Method of ensuring the waste stream characterization remains reliable between sampling campaigns, including an estimate of its reliability as an indicator of correct characterization. Depending on the process involved, gross measurements, process indicators, or other techniques might be appropriate

- Frequency of recharacterization - if sampling and analysis are required, these must be performed annually, at a minimum, and more frequentiy if the waste generating process is subject to changes.

- Characterization of Batch Waste Streams

If the waste is being generated through a short-term or infrequent operation, such that the composition of the waste is expected to vary appreciably over time, the waste could be characterized as a batch process. For such operations, the waste certification summary should describe the method for determining batch sizes and the mechanism for grouping waste into batches.

Batches can be defined by the specific waste generating operation with several similar operations grouped together (e.g., the applicable waste collected from several different chemistry laboratories), by the type of waste being generated (e.g., waste oils regardless of the point of origin), by point of origin (e.g., all applicable waste - either soil, liquid, or sludge, but not combinations of the three - from a given structure, regardiess of the generating process), or by some other method appropriate to the specific onsite generating unit or offsite generator. For this type of waste stream, the following information should be included in the waste certification summary:

- Method of grouping waste into batches (e.g., by waste type, by point of origin) 
WHC-SD-EN-WAP-004, Rev. 0

- Size of batches characterized in this manner (e.g., the amount of waste collected in 1 week, the number of containers)

- Waste characterization technique (e.g., sampling and analysis or process knowledge).

\subsubsection{Process Knowledge}

If process knowledge is used in the characterization process, a complete description of the process generating the waste [e.g., original product material safety data sheets (MSDS)] and published characterization methodology on the specific waste stream and/or characterization methodology on similar waste streams must be provided. Field analysis can be used to confirm process knowledge.

If adequate process knowledge exists to ensure a particular constituent is not present in the waste, there is no requirement to analyze for that constituent. However, the waste certification summary must establish that there is no reason to suspect the constituent is in the waste. This can be accomplished by including a detailed process description and/or published data of the process.

\subsubsection{Sampling and Analys is}

In cases where process knowledge is unavailable or incomplete, the onsite generating units and/or offsite generators characterize the waste by sampling and analyzing the waste stream. Knowledge of the history and origin of the waste can be used to decide the analytical testing needed to determine the dangerous constituents of the waste (e.g., if no reason exists to suspect certain chemical compounds like pesticides, there is no reason to test for such parameters).

The onsite generating units and/or offsite generators determine the appropriate sampling method, conduct all field and sampling quality assurance and quality control $(Q A / Q C)$, arrange for and coordinate with appropriate analytical laboratories, and document the sampling and analys is activities. The onsite generating units and/or offsite generators must certify that the waste analysis information is complete and accurate. For field activities, requirements will follow SW-846 (EPA 1986). Analytical laboratories will follow requirements stated in the Hanford Analytical Services Quality Assurance Plan (DOE/RL-94-55).

\subsubsection{Analytical Methodologies}

Specific analytical methodologies that should be used for each parameter should adhere to the guidance provided in SW-846 (EPA 1986), other pertinent references accepted by Ecology and/or the DOE-RL and other equivalent methods approved by Ecology and/or the DOE-RL. 
WHC-SD-EN-WAP-004, Rev. 0

\subsection{PRE-SHIPMENT REVIEH}

Pre-shipment review takes place before waste can be scheduled for transfer or shipment to the 224-T TRUSAF. The review focuses on whether the waste stream is accurately defined and the LDR status determined correctly. Only waste determined to be acceptable for storage is scheduled. This determination is based on the information provided by the onsite generating unit or offsite generator. The following section discusses the pre-shipment review process.

\subsubsection{Pre-Shipment Review Process}

For each waste transfer or shipment that is a candidate for storage, the onsite generating unit or offsite generator provides (1) all pertinent chemical, radiological, and physical data requested on the shipping paper;

(2) other supporting documentation such as MSDS, analytical data, etc.;

(3) a description of the waste contents on the container inventory record; and

(4) LDR notification/certification information or equivalent documentation (e.g., national capacity variance, contained-in determination variance, etc.) as applicable. The pertinent information is entered into the Solid Waste Information Tracking System (SWITS).

Based on waste identification information provided, the waste designation is reviewed to ensure consistency with waste designations per WAC 173-303-070, as well as for technical accuracy to ensure the waste meets the waste acceptance criteria. If the transfer or shipment information is found to be acceptable, a final operations review is completed and the transfer or shipment is scheduled.

Where potential nonconformances exist in the information provided, waste characteristics do not match the waste certification summary, or additional constituents are expected to be present that do not appear on the documentation, the onsite generating unit or offsite generator is contacted by the 224-T TRUSAF operating organization or an approved designated organization for resolution.

\subsubsection{Methodology to Ensure Compliance with Land Disposal Restrictions Requirements}

Mixed waste accepted for storage at the 224-T TRUSAF must either meet or identify the treatment necessary (identified in 40 CFR 268) to be considered for storage at the 224-T TRUSAF. The 224-T TRUSAF does not conduct treatment activities (e.g., absorption, neutralization, etc.,); therefore, waste needing treatment to meet LDR requirements will be conducted at permitted treatment units. All onsite generating units and offsite generators are subject to LDR or any LDR-related variances and are required to submit all the notifications and certifications described in 40 CFR 268.7. The following are general requirements for notifications and supporting documentation. 
- The waste is subject to LDR and the onsite generating unit and offsite generator or a permitted treatment unit has treated the waste.

- The onsite generating unit or offsite generator or a permitted treatment unit supplies the appropriate LDR certification information and the analytical data that demonstrate compliance with the LDR treatment standards of 40 CFR 268 and WAC 173-303-140.

- The waste is subject to LDR and the onsite generating unit or offsite generator has determined that the waste naturally meets the LDR treatment standard for disposal.

- The onsite generating unit or offsite generator supplies the appropriate LDR certification information and analytical data necessary to demonstrate compliance with the LDR treatment standards of 40 CFR 268 and WAC 173-303-140.

- If the onsite generating unit or offsite generator develops the certification based on process knowledge, analytical data also might be necessary to demonstrate compliance with the appropriate LDR treatment standard.

- The waste is subject to an exemption from a prohibition on 1 andfill disposal.

- The onsite generating unit and offsite generator submits a notice stating the waste is not prohibited from land disposal as required by 40 CFR 268.7 (a)(3).

A representative sample of the waste could be required to be submitted for analysis to ensure that LDR requirements are met. This sample could be submitted directly to a laboratory for analysis.

\subsection{WASTE VERIFICATION}

Waste verification, which includes LDR verification, consists of testing key physical and chemical properties. Waste verification parameters are selected based on the following criteria:

- The need to identify restricted waste

- Parameters important to the proper management of waste at the 224-T TRUSAF

- Parameters that can be used to corroborate that waste recejved matches the identity of waste specified on accompanying transfer or shipping papers

- The need to protect employees, the public, and the environment

- Verify waste received is LDR compliant as applicable. 
WHC-SD-EN-WAP-004, Rev. 0

Incoming waste verification is accomplished by reviewing applicable documentation and waste tracking forms or manifests against the waste. Selection of waste for verification is based on the following criteria.

- For radioactive only (non-mixed) waste containers stored in the 224-T TRUSAF, an adequate verification rate based on process knowledge must be used.

- For containers stored in the 224-T TRUSAF, at least 5 percent or an alternative rate, based on process knowledge and/or analytical data, must be used.

Verification is performed using a combination of nondestructive examination, physical examination, and/or chemical screening. Verification is performed by the 224-T TRUSAF operating organization or a designated organization during the waste acceptance process at the 224-T TRUSAF.

The following special materials might be excluded from verification by chemical sampling:

- Waste containers are not opened because of as low as reasonably achievable (ALARA) concerns

- Empty product containers

- Single substance spill material

- Off-specification, contaminated, and/or outdated commercial products in the original product container

- Contaminated debris and asbestos (does not include liquids or soils)

- Other special-case situations handled on a case-by-case basis.

Special materials have been exempted from chemical screening because these materials potentially are hazardous materials (e.g., remote handled, asbestos); are well defined and nonvariable (e.g., single substance spill material or off-specification products); or are unusually difficult to sample and analyze (e.g., empty product containers, contaminated debris, or demolition materials). For these exceptions, the onsite generating unit or offsite generator supplies sufficient chemical and physical characteristics for proper storage of the waste.

The following material cannot be verified by nondestructive examination:

- Container is shielded.

- Container has classified waste.

- Container is remote-handled waste. 
- Container cannot be received for nondestructive examination because of safety, equipment, or design limitations.

The following material cannot be verified by visual examination:

- Container would be damaged during opening.

- Container has a surface dose rate of 20 millirem per hour or greater (unshielded).

- Container alpha curie loading is greater than 10 nanocuries per gram.

- Container has classified waste.

- Container is remote-handled waste.

- Container cannot be visually examined because of safety, equipment, or design limitations.

The methods for ensuring representative sampling are presented in Section 3.0. As practical, the sampling techniques used for specific types of waste correspond to those referenced in SW-846 and WAC 173-303. The analytical methods chosen for the verification parameters are described in Appendix A.

\subsection{CORRECTIVE ACTIONS}

Corrective action is necessary when significant discrepancies or nonconformances are identified. A11 applicable acceptance criteria must be met. Nonconformances must be resolved or addressed before accepting the waste for storage at the 224-T TRUSAF. Depending on the severity of the nonconformance, the action for noncompliance could range from conditional acceptance to rejection of the entire waste transfer or shipment. The following sections describe nonconformances and the resolution process.

\subsubsection{Manifest Discrepancies}

Manifest and/or onsite waste tracking form discrepancies are significant discrepancies of quantity or type between the dangerous waste identified by documentation and the dangerous waste that the 224-T TRUSAF operating organization actually receives. Significant discrepancies are obvious physical or chemical differences in dangerous constituents that can be discovered through physical or chemical screening, which would cause the waste to be mismanaged.

\subsubsection{Nonconformances}

The following are examples of nonconformances that require corrective action: 
WHC-SD-EN-WAP-004, Rev. 0

- Items in a waste container not accounted for on documentation or items not in the container but documented

- Free liquids except condensate

- Extensively damaged, leaking, or open containers

- Waste with appearance discrepancies.

\subsubsection{Resolution of Nonconformances and Manifest Discrepancies}

The following activities are conducted when nonconformances and waste tracking form and/or manifest discrepancies are encountered.

- Incorrect or incomplete entries on the waste tracking forms, Uniform Hazardous Waste Manifest, or other shipping papers can be corrected or completed with concurrence of the onsite generating unit or offsite generator, and the 224-T TRUSAF operating organization. Corrections are made by drawing a single 7 ine through the incorrect entry. corrected entries are initialed and dated by the individual making the correction.

- The waste packages can be held in an appropriate staging area and the onsite generating unit or offsite generator requested to provide written instructions for correcting the condition before the waste is accepted.

- Waste packages can be returned as unacceptable.

- The onsite generating unit or offsite generator could be requested to correct the condition on the Hanford Facility before the waste is accepted.

- If a noncompliant mixed waste package is received from an offsite generator, and the waste package is nonreturnable because of condition, packaging, etc, , and if an agreement on disposition cannot be reached among the involved parties, the issue will be referred to the DOE-RL, Ecology, and other appropriate regulatory agencies for resolution.

- An evaluation will be performed to determine the need to sample previously accepted waste from the noncomplying onsite generating unit or offsite generator to determine if any of the waste has the potential for similar nonconformances.

For offsite generators, the DOE-RL provides notification to Ecology of unreconciled manifest discrepancies that are not resolved within 15 days. Discrepancies for onsite generating units are handled internally with no notification. 


\subsubsection{Periodic Evaluation of Nonconformances}

A11 nonconformances from an onsite generating unit or offsite generator are reviewed periodically to determine if waste generation and management practices are satisfactory. Depending on the review, verification percentages could be adjusted for a given waste stream or other action, such as recharacterization of the waste stream, might be required.

\subsection{ACCEPTING THE WASTE}

When the waste has been evaluated, the incoming waste acceptance process has been completed, and nonconformances have been resolved or addressed, the following process is followed for receipt of waste.

- The shipment is compared to the shipping paperwork to verify that the paperwork and shipment match

- The containers are verified to ensure they are in acceptable condition for receipt (e.g., no bulging, corrosion, loose lids, punctures, etc.)

- The manifest is examined and approved

- The manifest is signed and dated

- The waste can proceed as directed to the disposal areas of the LLBG.

- The waste can proceed as directed to the storage areas of the 224-T TRUSAF.

Copies of the following records for each waste stored in the 224-T TRUSAF, as applicable, are maintained by the 224-T TRUSAF operating organization or another approved organization:

- Al1 records providing a description of the waste

- Documentation identifying the dangerous characteristics of the waste

- Laboratory reports with chemical and physical analysis of samples

- Manifests or onsite waste tracking forms.

The onsite generating units and offsite generators maintain copies of onsite waste tracking forms, manifests, and associated documentation identifying the waste characteristics and assigned waste designations.

\subsection{MANIFEST SYSTEM}

The Hanford Facility has one EPA/State identification number as required by WAC 173-303-060, and all TSD units on the Hanford Facility are part of a single dangerous waste facility. Therefore, onsite transfers of dangerous or mixed waste are not subject to the manifesting requirements specified in WAC 173-303-370 and -180. However, a11 onsite waste transfers are conducted 
WHC-SD-EN-WAP-004, Rev, 0

in a manner to ensure protection of human health and the environment. Onsite waste tracking systems voluntarily are used for transporting waste.

For application in this document, the term 'offsite waste' is defined as mixed waste shipped to the 224-T TRUSAF from:

- Any generator or generating unit that is located in an area that is not part of the contiguous Hanford Facility and/or

- Any generator or generating unit from which the shipment of waste is transported over a public access roadway.

Offsite waste shipments are not exempt from the requirements of WAC $173-303-370$ and -180 .

After scheduling the shipment, the following occurs.

- An offsite generator completes a Uniform Hazardous Waste Manifest for each shipment. An onsite generating unit completes an onsite waste tracking form.

- The transporter receives the waste, and dates and signs the Uniform Hazardous Waste Manifest or onsite waste tracking form. The onsite generating unit or offsite generator dates, signs, and retains a copy of the manifest or the onsite waste tracking form.

- The waste is transported to the 224-T TRUSAF using onsite transportation personnel, or private carrier as applicable. Transporters of offsite mixed waste must have an EPA/State ident ification number.

Offsite waste arriving at the Hanford Facility is inspected by receiving personnel. Receiving personnel inspect the waste containers for damage and proper labeling when feasible, and review the transportation documentation for completeness and accuracy. If discrepancies are identified, the shipment is not allowed on the Hanford Facility until the discrepancies are resolved. If the shipment passes inspection, the shipment proceeds to the 224-T TRUSAF or other approved TSD.

Following receipt of the waste, the 224-T TRUSAF operating organization ensures the following.

- Manifest discrepancies, if any, are noted on the Uniform Hazardous Waste Manifest or the onsite waste tracking form.

- The transporter is given a signed copy of the Uniform Hazardous Waste Manifest or the onsite waste tracking form, per WAC 173-303-370(2)(c).

- For offsite waste shipments, a 224-T TRUSAF operating organization transmits the original Uniform Hazardous Waste Manifest to the offsite generator within 30 days of waste receipt. For onsite waste 
transfers, the 224-T TRUSAF operating organization transmits a copy of the waste tracking form to the onsite generating unit.

The Uniform Hazardous Waste Manifests and onsite waste tracking forms are maintained in the 224-T TRUSAF operating record.

If a waste arrives at the 224-T TRUSAF in a condition (e.g., bulging, etc.) that could present a hazard to public health or the environment, the building emergency plan for the 224-T TRUSAF could be implemented.

\subsection{TRACKING SYSTEM}

The 224-T TRUSAF operating organization maintains a record of waste received, and rejected and returned, including generator name(s), waste tracking numbers, and the reason the waste was rejected.

On approval for storage, the waste is assigned a unique number used for tracking waste movement and final disposition. This number is written on the manifest or waste tracking form and is placed on a label for each container.

\subsection{ADDITIONAL REQUIREMENTS FOR WASTE GENERATED OFFSITE}

There are no additional requirements for waste generated offsite.

\subsection{METHODOLOGY FOR IGNITABLE, REACTIVE, OR INCOMPATIBLE WASTE}

The 224-T TRUSAF handles ignitable, reactive, and incompatible waste. All waste handling is performed according to applicable regulations and in a manner that minimizes the threat to human health or the environment. The following specific precautions are taken.

- No smoking is allowed in the 224-T TRUSAF.

- No open flames, sparking devices, cutting or welding, hot surfaces, or static or friction sparks are allowed in 224-T TRUSAF while ignitable or reactive waste is present, unless an appropriate authorization has been received from the responsible internal safety organizations. This authorization details the work restrictions necessary to ensure that ignitable or reactive waste is not exposed to conditions that could cause detonation or ignition.

- Compatibility testing is conducted using the methods listed in this WAP before mixing any two types of waste.

- Incompatible waste is segregated into separate containers and stored apart from each other. 


\subsection{SAMPLING METHODOLOGY}

Specific sampling processes depend on both the nature of the material and the type of packaging (Table 3-1). This section describes the sampling methodology.

\subsection{SAMPLING METHODOLOGY}

As practical, the sampling methodology used for specific types of waste correspond to those references in SW-846 and WAC 173-303 (Table 3-1).

\subsection{SAMPLING STRATEGIES}

The ALARA principle and other worker safety concerns impose a practical limit on the extent of verification evaluation that can be performed on a waste load. The current upper limit set on the surface dose rate for opening containers is 20 millirem per hour. Deviations from this limit can be allowed by a radiation work permit.

In addition to the 20 millirem per hour restriction, the extent of verification evaluation could be limited by an industrial hygienist, who could make a decision that a container not be opened because of the potential for chemical exposure. In both cases, the decision not to open a container is documented in the field files, signed and dated by the industrial hygienist or an authorized representative of radiological control as appropriate, and kept as part of the 224-T TRUSAF 0perating Record. If a waste package is deemed to be hazardous to worker health, additional containers will be examined for sampling suitability.

Samples from individual containers or at the point of generation can be composited providing the samples are: (1) from a single onsite generating unit or offsite generator, (2) related to one waste specification record, or (3) similar in appearance and composed of compatible material. If the sample material shows significant variation in moisture content, texture, or color, this material should not be composited to avoid masking potentially regulated constituents.

Sampling of small containers will vary with the nature of the material, as well as the type of container. However, the appropriate SW-846 method or protocol will be followed with each sampling campaign. Solid material that cannot be penetrated to an appropriate depth with standard sampling equipment will be sampled to the best extent possible with available equipment. otherwise a representative sample will be taken by drawing a full vertical sample of the waste container. 
Table 3-1. 224-T Transuranic Waste Storage and Assay Facility Sampling Methods.

\begin{tabular}{|c|c|c|c|c|}
\hline \multirow[b]{2}{*}{ Waste type } & \multicolumn{2}{|c|}{ Reference in SW-846 (EPA 1986) } & \multicolumn{2}{|c|}{ Reference in WAC 173-303 } \\
\hline & Waste type & Sampling method & Waste type & Sampling method \\
\hline Liquids & $\begin{array}{l}\text { Free-flowing liquids } \\
\text { and slurries }\end{array}$ & COLIHASA, SH-846, Chapter 9 & $\begin{array}{l}\text { Extremely viscous } \\
\text { liquid }\end{array}$ & ASTM Standard 0140-70 \\
\hline Sol idified liquids & Sludges & Trier, sW-846, Chapter 9 & MA & NA \\
\hline sludges & Sludges & Trier, SW-846, Chapter 9 & MA & NA \\
\hline Soils & $\begin{array}{l}\text { Sand or packed powders } \\
\text { and granules }\end{array}$ & Auger, sW-846, Chapter 9 & Soil-like material & ASTM Standard D1452-65 \\
\hline Het absorbents & $\begin{array}{l}\text { Moist powders or } \\
\text { granules }\end{array}$ & Trier, SH-846, Chapter 9 & NA & MA \\
\hline \multirow[t]{3}{*}{$\begin{array}{l}\text { Process solids and } \\
\text { salts }\end{array}$} & $\begin{array}{l}\text { Moist powders or } \\
\text { granules }\end{array}$ & Trier, sH-846, Chapter 9 & MA & NA \\
\hline & Dry powders or granules & Thief, sh-846, Chapter 9 & $\begin{array}{l}\text { Crushed or powdered } \\
\text { materials }\end{array}$ & ASTM Standard $0346-\pi 5$ \\
\hline & $\begin{array}{l}\text { Sand or packed powders } \\
\text { and granules }\end{array}$ & Auger, SH-846, Chapter 9 & Soil-like material & ASTM Standard D1452-65 \\
\hline \multirow{2}{*}{ Ion exchange resins } & Dry powders or granules & Thief, sW-846, Chapter 9 & Fly ash-like material & ASTM Standerd D2234-86 \\
\hline & $\begin{array}{l}\text { Sand or packed powders } \\
\text { and granules }\end{array}$ & Auger, SW-846, Chapter 9 & Soil-like material & ASTM Standard D1452-65 \\
\hline
\end{tabular}

13

COLIWASA = composite liquid waste sampler .

NA $=$ not applicable. 
WHC-SD-EN-WAP-004, Rev. 0

The following sections discuss the overall objectives of the waste analysis program, as well as the specific data quality objectives (DQOS) (Table 4-1). Specific field and laboratory $Q A / Q C$ requirements to meet these objectives also are addressed.

\subsection{OBJECTIVES OF THE WASTE ANALYSIS PROGRAN}

The primary objective of the waste analysis program is to ensure that the waste stored at the 224-T TRUSAF is characterized adequately for proper storage. The waste analysis program is designed to meet this objective, and the general waste analys is requirements of WAC 173-303-300 and the disposal restrictions of 40 CFR 268 if applicable.

\subsection{DATA QUALITY OBJECTIVES}

The data used to support the 224-T TRUSAF waste analysis program need to be scientifically sound, of known quality, and thoroughly documented. In DQOs for the waste characterization and verification program, the standard parameters (precision, accuracy, compatibility, completeness, and representativeness) were considered (DOE/RL-94-55).

The field data for verification testing will meet EPA quality level I and II criteria. The laboratory data for chemical analyses will meet EPA quality level III criteria. Data from radiological analyses will meet EPA quality level $v$ criteria (DOE/RL-94-55).

\subsection{FIELD QUALITY ASSURANCE AND QUALITY CONTROL}

Field blanks and replicates are required for samples analyzed in the field as part of verification testing as well as for samples submitted for laboratory analysis. The number of field $Q A$ samples is 10 percent of the total number of field samples taken. The 10 percent criterion commonly is accepted as a minimum number of $Q A / Q C$ samples.

\subsection{LABORATORY QUALITY ASSURANCE AND QUALITY CONTROL}

The laboratory $Q A / Q C$ requirements outlined in the following apply to laboratory analyses requested by the 224-T TRUSAF operating organization for residuals characterization or for recharacterization as part of a corrective action. Most laboratory analyses for waste characterization are conducted by the onsite generating units or offsite generators, who are required to document their certification programs (refer to Section 2.0). 
WHC-SD-EN-WAP-004, Rev. 0

1 The daily quality of analytical data generated in the contracted analytical laboratories is controlled by the implementation of an analytical laboratory QA plan.

Before commencement of the contract for analytical work, the laboratory submits its QA plan to the waste analysis project manager and the QA officer for approva1. At a minimum, the plan documents the following:

- Sample custody and management practices

- Sample preparation and analytical procedures

- Instrument maintenance and calibration procedures

- Internal QA/QC measures, including the use of method blanks

- Sample preservatives used

- Analyses requested. 


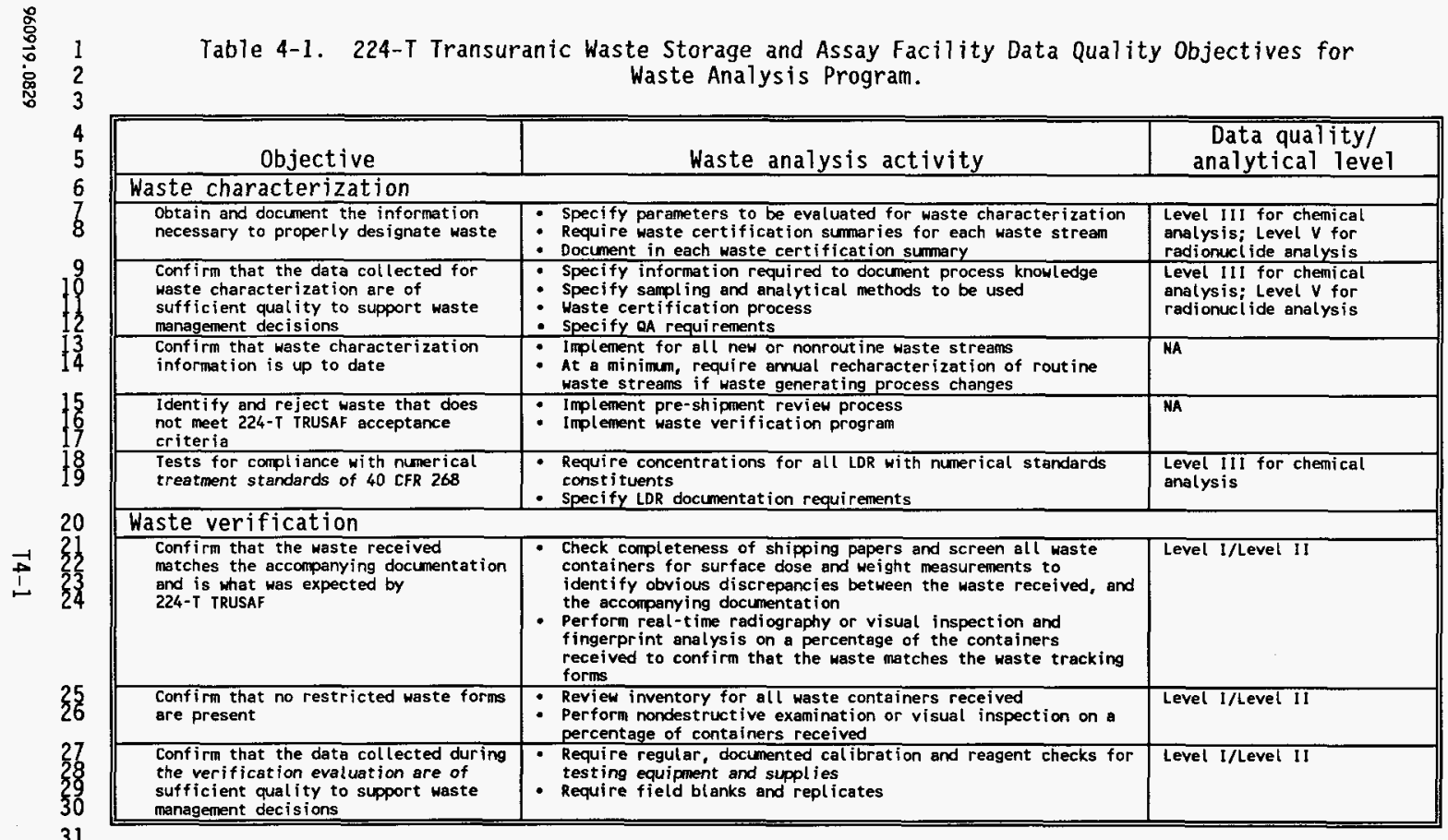

LDR = land disposal restriction.

$N A=$ not applicable. 
WHC-SD-EN-WAP-004, Rev. 0

\subsection{SPECIAL REQUIREMENTS FOR LAND DISPOSAL RESTRICTION WASTE}

The 224-T TRUSAF operating organization ensures that all mixed waste restricted from 1 and disposal meets or describes the appropriate treatment standards of 40 CFR 268, Subpart D, before acceptance for storage. The 224-T TRUSAF operating organization will not transfer for disposal any mixed waste restricted under 40 CFR 268, Subpart $C$, that does not meet the treatment standards of 40 CFR 268, Subpart D, unless:

- Such waste is subject to a national variance

- Contained-in petition is granted

- Equivalent treatment under 40 CFR 268.42(b) is granted

- A petition under 40 CFR 268.6 is granted

- An extension under 40 CFR 268.5 is given

- A treatment standard variance under 40 CFR 268.44 is granted.

Listed waste numbers F020, F021, F022, F023, F026, and F027 (dioxin-containing waste) are prohibited from land disposal; the 224-T TRUSAF operating organization does not accept waste containing these waste numbers. Lab packs are accepted for storage until treatment becomes available.

Waste containing halogenated organic compounds (HOCs) in total concentration greater than or equal to 1,000 milligrams per kilogram are prohibited from 1 and disposal and are accepted for storage at the 224-T TRUSAF until treated. Specific methods for analyzing the HOCs [otherwise referred to as total organic halides (TOX)] are described in Appendix B.

The 224-T TRUSAF operating organization is responsible for obtaining detailed physical and chemical analys is in accordance with Section 3.0. This applies to waste that is both treated and that naturally meets the treatment standards specified in 40 CFR 268. At a minimum, corroborative testing will be conducted annually on a designated sample (e.g., the pre-acceptance sample). Waste characterization might be required more frequently under the following circumstances.

- A new waste stream is generated.

- A process generating the waste changes.

- The waste characteristics are highly variable from load to load.

- The 224-T TRUSAF operating organization has reason to suspect a change in the waste based on inconsistencies in manifesting, packaging, or labeling of the waste.

Each waste is analyzed for those LDR constituents contained in the listed and characteristic numbers identified by the onsite generating unit or offsite generator that cause the waste to be dangerous. Onsite generating units or offsite generators might test waste or use process knowledge to determine LDR status. Treatment standards to which the waste is subject use 40 CFR 268 , Appendix 1, SW-846, or EPA-600 methods. However, when it can be shown that a 
WHC-SD-EN-WAP-004, Rev. 0

1 treatment standard has been met through an analysis other than for the 2 established analysis methods, the requirement for the analysis of the 3 treatment standard may be waived by the 224-T TRUSAF operating organization. 


\subsection{RECORDKEEPING}

This WAP is maintained by the 224-T TRUSAF operating organization or by other approved organizations. Laboratory documents are maintained by the laboratories. Records associated with this WAP and waste verification program are maintained by the 224-T TRUSAF operating organization or another approved designated organization.

A copy of the waste storage record for each waste stream accepted at the 224-T TRUSAF also is maintained. Onsite generating units and offsite generators maintain their sampling and analysis records, and the 224-T TRUSAF operating organization could request copies of this information. All records and results of waste analysis are maintained in the 224-T TRUSAF operating record.

This WAP will be revised under the following circumstances.

- Whenever test methods are changed.

- Whenever changes occur in the waste acceptance criteria or the waste categories accepted for storage that might require a change in the parameters to be tested.

- Whenever referenced personnel, organizations, or procedures are changed.

- Whenever regulation changes occur that affect the WAP.

The DOE-RL may implement any proposed change once Ecology is notified. However, if the change eventually is disapproved, the DOE-RL will be responsible for fulfilling any requirements that were not met because of implementation of the change.

This WAP is maintained as a controlled document under the existing guidelines for document control within the 224-T TRUSAF operating organization. Documents are maintained in the 224-T TRUSAF operating record and are forwarded to the onsite document control organization for permanent storage. 
WHC-SD-EN-WAP-004, Rev. 0

This page intentionally left blank. 
WHC-SD-EN-WAP-004, Rev. 0

\subsection{REFERENCES}

ASTM, 1982, Annual Book of ASTM Standards, Parts 15, 19, and 31, American Society for Testing and Materials, Philadelphia, Pennsylvania.

DOE/RL-94-55, Hanford Analytical Services Quality Assurance P7an, Rev. 0, U.S. Department of Energy, Richland Operations Office, Richland, Washington.

EPA, 1986, Test Methods for the Evaluation of Solid Waste: Physical/Chemical Methods, SW-846, 3rd Edition as amended by Update I, U.S. Environmental Protection Agency, Washington, D.C.

EPA, 1987, Data Quality Objectives for Remedial Response Activities, Development Processes, EPA/540-87-003, U.S. Environmental Protection Agency, Washington, D.C. 
WHC-SD-EN-WAP-004, Rev. 0

This page intentionally left blank. 
WHC-SD-EN-WAP-004, Rev. 0

$\begin{array}{rr}1 \\ 2 \\ 3 \\ 4 \\ 5 \\ 6 \\ 7 & A \\ 8 & \\ 9 & B \\ 10 & \\ 11 & C\end{array}$

\section{APPENDICES \\ CONTENTS}

A ANALYTICAL PROCEDURES AND RATIONALE

9 B TOTAL ORGANIC HALIDES SCREENING FOR INCOMING WASTE ACCEPTANCE

11 C FINGERPRINT PARAMETER SELECTION 
WHC-SD-EN-WAP-004, Rev. 0

This page intentionally left blank. 
WHC-SD-EN-WAP-004, Rev. 0

\section{APPENDIX A}

3

4.

ANALYTICAL PROCEDURES AND RATIONALE 
WHC-SD-EN-WAP-004, Rev. 0

1

2

4

5

This page intentionally left blank. 
WHC-SD-EN-WAP-004, Rev. 0

\section{APPENDIX A}

\section{ANALYTICAL PROCEDURES AND RATIONALE}

These analytical procedures are designed to identify or screen specific waste components. Because the characterization provides information concerning the distribution and nature of waste constituents within the waste material, and the 224-T TRUSAF operating organization is merely identifying that previously submitted information is correct rather than completely characterizing the waste, a less comprehensive sampling and analytical approach is appropriate.

The analytical screening parameters that could be used for waste received at the 224-T TRUSAF for storage, associated rationale, and methods for these analyses are as follows.

- Physical description is used to determine the general characteristics of the waste. This facilitates subjective comparison of the sampled waste with previous waste descriptions or samples. Also, a physical description is used to verify the observational presence or absence of free 1 iquids other than condensate.

Methods--samples are inspected and the physical appearance of the waste is recorded. Real-time radiography and/or visual examination are used.

- Radioactivity screen is used to quantify radionuclides for verification of transuranic radionuclide content, non-transuranic radionuclide content, and the waste classification (i.e., low-level waste or transuranic)

Methods--a sample of the waste is passed by a geiger counter, survey meter, or a waste container is assayed using passive-active neutron or segmented gamma scanning techniques.

- Headspace volatile organic compound analysis is performed to determine the presence or absence of solvents or other volatile organic compounds in waste. This is one of the few methods available to evaluate the presence of volatile organic compounds that could be associated with heterogeneous materials.

Methods--a sample of the headspace gases in a container is analyzed by one or more of the following: Fourier transform infrared spectroscopy, gas chromatography/mass spectroscopy, HNU, organic vapor analyzer, and colorimetric tubes. 
- Paint filter liquids test is used to verify the presence or absence of free liquid in solid or semisolid material to be landfilled.

Method--to a standard paint filter, 100 centimeters or 100 grams of waste are added and allowed to settle for 5 minutes. Any liquid passing through the filter signifies failure of the test (SW-846, Method 9095).

- $\mathrm{pH}$ screen is used to identify the $\mathrm{pH}$ and corrosive nature of an aqueous or solid waste, aid in establishing compatibility strategies, and to indicate the proper storage location in the 224-T TRUSAF.

Methods--full range $\mathrm{pH}$ is used for the initial screening. If the initial screen indicates a ph below 2 or above 12.5, a $\mathrm{pH}$ meter is used. The $\mathrm{pH}$ meter is used directly on liquid samples and on the free liquid portion of liquid/solid samples. For solid materials, the $\mathrm{pH}$ of the solution from a $1: 1$ slurry of water to waste is used (or ASTM, Method D4980).

- Flammability potential screen is used to determine the fire-producing potential of the waste. This test can be applied to waste liquids, solids, and semisolids.

Methods--1iquids are tested using the HAZCAT ${ }^{1}$ combustibility, char and/or oxidizer tests; solids and semisolids are tested using the HAZCAT char and/or oxidizer tests.

- Water reactivity screen is used to determine if the waste has the potential to react vigorously with water to form gases or other reaction products.

Method--approximately 5 grams of solid or 5 milliliters of liquid waste are mixed with about 5 milliliters of water. For liquid waste, water is added to the waste. The solution is observed for evidence or fuming, bubbling, or spattering. These reactions are considered to be positive evidence that the waste is water reactive.

- Cyanide screen indicates whether the waste produces hydrogen cyanide upon acidification below pH 2 .

Method--to a test tube or beaker containing approximately 5 milliliters of sample, an equal amount of freshly prepared ferrous ammonium citrate is added. Then 3 normal hydrochloric acid is used to reduce the $\mathrm{pH}$ of the solution to about 2.0. A deep blue color indicates the presence of cyanide. The test can detect free cyanide and complex cyanides in concentrations above 200 parts per milition.

1 HAZCAT is a registered trademark of Haztech Systems Incorporated, 
- Sulfide screen is used to indicate if the waste produces hydrogen sulfide upon acidification below pH 2 .

Methods--approximately 5 milliliters of sample is added to beaker or test tube and enough 3 normal hydrochloric acid is added to bring the $\mathrm{pH}$ down to 2.0. A sulfide test strip is placed in the solution. If the paper turns brown or silvery black, the presence of sulfides in the sample is indicated. If there is no color change, the total sulfides are reported as nondetectable.

- Metals and elements screen is used to determine the presence of regulated quantities of heavy metals in the waste and confirm the presence or absence of other inorganic elements. This method is used as a confirmation of other test results.

Method--waste samples are tested using an $x$-ray fluorescence spectrometer and/or the toxicity characteristics leaching procedure extraction method (SW-846, Method 1311). For the $x$-ray fluorescence spectrometry method, spectral data are obtained by putting a small sample of waste in special sample cups or by holding the detector up to the waste to be analyzed. The resulting spectra are analyzed for the presence of elements and heavy metals.

- Volatile and semivolatile compounds screen is used to evaluate the presence or absence of volatile and/or semivolatile organic compounds in the waste, and to verify the treatment standards associated with organic chemical content.

Methods--waste is tested using fourier transform infrared spectroscopy, fourier transform raman spectroscopy, and/or gas chromatography/mass spectroscopy. Depending on the waste matrix, an experienced spectroscopist uses the testing method best suited for the waste and interprets the results.

- PCB screen is used to indicate whether PCBs are present in oil-bearing waste and to determine if the waste needs to be managed in accordance with the regulations prescribed in the Toxic Substance Control Act of 1976 .

Method--the tests to be conducted include the HAZCAT beilstein test, and/or the appropriate organic chlorine test. 
WHC-SD-EN-WAP-004, Rev. 0

1
2
3
4
5

This page intentionally left blank. 
WHC-SD-EN-WAP-004, Rev. 0

APPENDIX B

TOTAL ORGANIC HALIDES SCREENING FOR INCOMING WASTE ACCEPTANCE 
WHC-SD-EN-WAP-004, Rev. 0

This page intentionally left blank. 
WHC-SD-EN-WAP-004, Rev. 0

\section{APPENDIX B}

\section{TOTAL ORGANIC HALIDES SCREENING FOR INCOMING WASTE ACCEPTANCE}

This appendix addresses the guidelines and processes by which the 224-T TRUSAF operating organization determines the applicability and demonstrates compliance with the LDR regulations for waste with HOCs. The appropriate screening methods will be used for TOX.

\section{Pre-Shipment Characterization for Halogenated Organic Compounds or Total Organic Halides}

A determination as to the applicability of the HOCs is made during the pre-shipment acceptance testing. This determination is based on the results of TOX analysis or based on results of the individual compounds listed in Appendix III of 40 CFR 268. This determination is made by the onsite generating unit or offsite generator as part of the information submitted to the 224-T TRUSAF operating organization.

\section{Waste Verification for Total Organic Halides}

The 224-T TRUSAF operating organization samples and analyzes at least 20 percent of all incoming waste streams that have pre-shipment TOX readings above 500 milligrams per kilogram to ensure the incoming waste arrives with ToX levels below 1,000 milligrams per kilogram.

If the incoming waste contains less than 1,000 milligrams per kilogram of TOX, the material is considered for land disposal if all other waste acceptance criteria are met. If the ToX test indicates greater than 1,000 milligrams per kilogram of TOX is present, the waste is subjected to further analysis to determine if the $\mathrm{HOC}$ concentration exceeds 1,000 milligrams per kilogram as described in the next section.

\section{Land Disposal Prohibition for Shipments with Excessive Levels of Total Organic Halides}

The 224-T TRUSAF operating organization will not transfer for disposal any mixed waste where waste analysis results exceeds 1,000 milligrams per kilogram of TOX unless the comprehensive analysis criteria are performed to demonstrate that the HOC level in such waste does not exceed 1,000 milligrams per kilogram. Laboratory analysis, in accordance with EPA approved methods, is performed to determine the concentration of each constituent 1 isted in Appendix III of 40 CFR 268. If the laboratory results indicate that the total concentration of the listed HOCs does not exceed 1,000 parts per million, the 224-T TRUSAF operating organization will transport this waste stream for 1 and disposal after recording these data in the operating record. 
Annual Total Organic Halides Analysis and Recharacterization of Waste for High Total Organic Halides

Annually, the 224-T TRUSAF operating organization analyzes a sample of each non-high TOX waste stream for recharacterization of the high TOX classification. The TOX analys is is performed on a sample taken from an incoming shipment. Should the waste exceed 500 milligrams per kilogram of TOX, the waste is recharacterized as a high TOX waste and thereafter is analyzed for TOX at the high TOX frequency. High TOX waste remains high TOX waste thereafter. The annual high TOX recharacterization is not required for high TOX waste because waste already is sampled at the high TOX frequency.

\section{Additional Recordkeeping Requirements for High Total Organic Halides Analys is Results}

The 224-T TRUSAF operating organization maintains the following

- A list of high TOX waste streams that are accepted at the 224-T TRUSAF

- The results of the annual characterization analysis for high TOX/non-high TOX waste

- The results of the incoming shipment analyses for Tox for both high TOX and non-high TOX waste.

\section{Total Organic Halides Screening Protocol Sample Preparation and Analysis}

Method 9020 or 9022 determines TOX as chloride in aqueous waste solutions. Using this method for analysis, the 224-T TRUSAF operating organization prepares and analyzes an extract for a11 waste that is nonaqueous in nature. The 224-T TRUSAF operating organization uses Method 3540 (soxhlet) or Method 3550 (sonification), which are extraction procedures described in SW-846 to prepare this extract. The extract is referred to as 'solid waste extracts'.

If significant stratification occurs in the waste, each layer might be composited in proportion to the estimated volume. These samples are mixed sufficiently to allow a representative sample of the waste to be analyzed. 
WHC-SD-EN-WAP-004, Rev. 0

APPENDIX C

FINGERPRINT PARAMETER SELECTION 
WHC-SD-EN-WAP-004, Rev. 0

1
2
3
4
5

This page intentionally left blank. 


\section{APPENDIX C \\ FINGERPRINT PARAMETER SELECTION}

The following parameters have been selected for fingerprint analysis of waste materials being received at the 224-T TRUSAF.

- Flammability or head space VOC/SVOC--Flammability tests will be conducted when safety conditions exist that eliminate the spread of radioactive material to the worker or environment via open $f 1$ ame testing. Head space analysis, volatile organic compounds, or semivolatile organic compound analysis will be used in place of open flame tests as needed using appropriate analytical equipment. oxidizing materials that could contribute to the propagation of a fire also will be analyzed.

- Paint filter liquid screening--When needed, this analysis will be used to determine if free liquids potentially are present in a waste shipment.

- $\mathrm{pH}-\mathrm{pH}$ screening is conducted to identify waste that might mobilize toxic materials and corrode storage containers.

- Organic halogen--This screening is conducted to identify the presence of persistent or land ban materials; a precursor for PCB screening if the test is positive.

- PCBs-- PCB waste is regulated specifically by federal and state regulations. These regulations must be met for storage of $\mathrm{PCB}$ waste at the 224-T TRUSAF.

- $\mathrm{H}_{2} \mathrm{O}$ Reactivity--This test is conducted to determine if a waste material has the potential to react vigorously with water or form toxic gases.

- Sulfide--This test is conducted to determine if a waste material might produce hydrogen sulfide, a toxic gas formed below pH 2 .

- Cyanide--This test is conducted to determine if a waste material might produce hydrogen cyanide below $\mathrm{pH} 2$.

- Metals--When needed, x-ray fluorescence or toxicity characteristic leaching procedure methods will be conducted. 
WHC-SD-EN-WAP-004, Rev. 0

1

2

3

4

This page intentionally left blank. 